\title{
Examination of Adolescents' Attention, Appetite and Nutritional Status
}

Fatma Nur Çelen MSc, Sinem Bayram PhD, Esen Yeşil PhD

Baskent University, Faculty of Health Sciences, Department of Nutrition and Dietetics, Ankara, Turkey.

Corresponding author, Fatma Nur Çelen: fncelen@hotmail.com

Address: 2475. street, 4/17, post code 06810, Ankara, Turkey; GSM: 05303183690

The authors declare no conflict of interest.

This study was approved by Başkent University Medical and Health Sciences Research Board and Ethics Committee (Project number: KA20 / 01) and supported by Başkent University Research Fund.

\section{ABSTRACT}

Aim: The aim of this study was to examine adolescents' attention levels, in which mood they tend to eat, their eating habits, and the relationship among these variables.

Methods: This study was conducted in February 2020 on 142 students in total, 69 (48.6\%) of them girls and 73 (51.6\%) of them boys who are studying at Süleymaniye Educational Institutions Bağlıca Secondary School in Turkey. Data were collected using a questionnaire with 38 questions and a 24-hr dietary recall to determine the personal characteristics and the eating habits of these adolescents; the D2 Attention Test was used to determine attention levels and the Emotional Appetite Questionnaire was used to identify appetite.

Results: $38.7 \%$ of participants were overweight and 23.2\% were obese. The D2 Attention test found that mean TN (total number of items processed) and concentration performance scores were correlated positively with age and negatively with body mass index for age. A significant and negative correlation was found between glucose intake and the TN scores.

Conclusions: A high risk of obesity was found in these secondary school students. At the same time, it is thought that there may be a relationship between individuals' macro and micronutrient consumption and their emotional eating tendency and attention levels. For this reason, it is important to detect and improve dietary habits of adolescents, which is a critical process for future generations.

Key Words: Adolescence, attention, emotional appetite, nutrition 


\section{INTRODUCTION}

Adolescence is defined as the period of attaining physical, cognitive and social maturity between childhood and adulthood. ${ }^{1}$ As a result of the significant increase in hormone levels, changes in physical appearance such as sexual maturation, facial structure and tone of voice occur. In addition, brain development continues. ${ }^{1,2,3}$ Processes such as neuron formation, cell loss, synaptic formation and pruning occurring during this period cause the morphological structure of the brain to be rearranged. ${ }^{4}$ In addition, a locational difference between the prefrontal cortex and the limbic system, which is related to issues such as emotional and behavioural tendencies, is most common in adolescence. This developmental difference between the regions of the brain causes individuals in this period to act with emotional behaviours compared to adults and to have difficulty with opposing impulsive motives. ${ }^{5,6}$

It is thought that mood has a 30-48\% effect on food intake. ${ }^{7}$ Considering that mood changes are more common in adolescence than at other developmental stages, this is considered to be a risky period in terms of emotional eating behaviour. ${ }^{8}$ Emotional eating behaviour varies according to the individual's character and emotional state and may result in binge eating behaviour in response to negative emotions such as anxiety, depression and anger. ${ }^{9,10}$ In the case of depression in normal individuals, gastric motility decreases as a result of the hyperactivity of the hypothalamic-pituitary-adrenal (HPA) axis, and the feeling of hunger is suppressed by providing glucose to the bloodstream. While hypophagia and decrease in body weight are observed in normal depressed individuals, in individuals with an emotional eating tendency food intake and body weight increase are associated with hypoactivation of the HPA axis. ${ }^{11}$

Attention can be defined as a general alertness or the ability to interact with the environment. ${ }^{12}$ It also constitutes the most basic process of the human mind and affects all cognitive processes such as memory and learning. ${ }^{13}$ Inattention and behavioural problems, which are frequently seen in Attention Deficit and Hyperactivity Disorder (ADHD), are associated with an inability of the autonomic nerve request to respond to momentary changes in environmental stimuli. ${ }^{14}$ ADHD, which is characterised by 3 major symptoms--attention deficit, hyperactivity and impulsivity--affects academic success negatively and is also associated with behaviours that cause distress in marital and business life, crime and drug addiction. ${ }^{15}$

There is no proven clear impact of foods on $\mathrm{ADHD}^{16}$ but there is some indicative evidence. Feingold, one of the first researchers to work on this topic, implemented a diet that eliminated food additives and food dyes in hyperactive children, and received positive feedback. ${ }^{17}$ The general view is that food dyes and preservatives can cause behavioural disorders in children with and without ADHD. However, it is not included in ADHD pathophysiology. ${ }^{18}$ According to some researchers, various allergies cause learning disabilities and behavioural problems. ${ }^{17}$ Physical reactions to food can trigger ADHD symptoms not only on the skin, gastrointestinal system or respiratory system, but also by affecting brain electrical activity. ${ }^{16}$ For this reason, an elimination diet has emerged through foods that increase immunoglobulin levels, which are the basis of allergies. ${ }^{18}$ In one study, individuals with ADHD were administered an elimination diet (a diet that included rice turkey, lamb, vegetable fruit margarine vegetable oil tea peach 
juice and juice) called the oligoantigenic diet, and it was observed that symptoms improved after 5 weeks of follow-up. ${ }^{19}$

Because of the physiological and psychological changes experienced in schoolage children, emotional disorders can often be seen, especially in children with exam anxiety, and these negative emotions can push individuals to emotional eating behaviour. Impulsivity is seen in individuals with emotional eating behaviour and food addiction. Since impulsivity is also at the forefront in ADHD, these two separate issues may be related to each other. ${ }^{12}$ At the same time, attention deficit is an important issue that needs to be researched, as it directly affects academic success. For these reasons, the aim of the study is to evaluate the nutritional status, eating habits, emotional appetite levels, and attention levels of adolescents and to examine the relationships among them.

\section{METHODS}

This study was carried out with 161 middle school students (5th, 6th, 7th, and 8th grades) between the ages of 10-15 at Süleymaniye Educational Institutions Bağlica Secondary School in Turkey in February 2020 and voluntarily accepted to participate in the study. This study was ethically approved by Başkent University Medical and Health Sciences Research Board and Ethics Committee (Project number: KA20 / 01) and supported by Başkent University Research Fund.

As a result of a preliminary statistical evaluation, the minimum total sample size was calculated as 146, with 5\% type I error probability and $85 \%$ power. The height and body weight measurement of 8 students and food consumption records of 3 students could not be obtained; 5 students completed the D2 attention test incorrectly. The exclusion criterion for this study is having a diagnosis of ADHD. 3 students were excluded from the study due to illness. As a result, this research was completed with 142 adolescents. All secondary school students who wanted to participate voluntarily were included in the study. All data were obtained through a collective interview in the classroom environment using the face-to-face interview technique, but each student filled in the questionnaire privately and none knew what the others wrote. The children and their parents were informed about the study and consent was obtained from both.

A questionnaire with 38 questions, a 24-hour food consumption record, and a 22item "Emotional Appetite Questionnaire" were administered. The "D2 Attention Test", which measures attention levels, was administered first in order not to distract the students. Participants' Body Mass Index (BMI) for age percentile and z score values were calculated using the World Health Organization (WHO) AnthroPlus program and measurements were made according to WHO specifications. ${ }^{20}$

The D2 attention test was developed by Brickenkamp (1981) to determine selective attention. ${ }^{21}$ It is applied to individuals between the ages of 9-60. The test can be applied individually or collectively in the classroom. The individual is expected to complete each line within 20 seconds, and the test containing 658 items should be completed within 8 minutes at the most. There are 3 different signed forms of the letters "d" and "p". These lines are located above, below, above and below the letters. Within the allotted time, the double-dashed letters $\mathrm{d}(\overline{\overline{\mathrm{d}}} \underline{\underline{\mathrm{d}}}$ or $\underline{\mathrm{d}})$ are to be marked (Figure 1). 


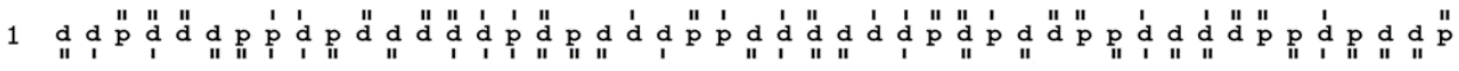

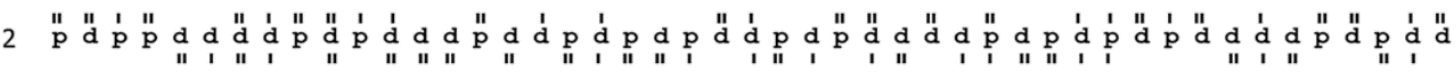

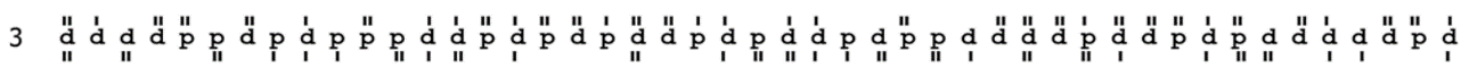

Figure 1. Sample of the D2 Attention Test

Psychomotor speed level (very good, good, normal, average, below average, poor) is evaluated according to the total number (TN score) marked correctly minus errors (TNE score). If the number of incorrectly marked (E2 score) letters is more than the number of correct letters (E1 score) that are not marked, there is a possibility of learning difficulties. The difference of more than 7 between the TN scores (TN max-min) is an indicator of fluctuation of attention. These points were calculated in the excel program that contains the standard table of the $\mathrm{D} 2$ attention test.

The emotional appetite questionnaire (EAQ) was developed by Nolan and colleagues. ${ }^{22}$ Individuals are asked to express the frequency of eating according to their emotional changes and the conditions they live in. A positive total score is obtained by adding positive emotions and situations, and negative total score values are obtained by adding negative emotions and situations. Although there is no cut-off score, it evaluates in which feelings and situations emotional eating may occur. Demirel and colleagues ${ }^{23}$ conducted a study of validity and reliability in Turkey.

IBM-SPSS (Statistical Package for the Social Sciences) 23 Statistical Package Program was used in the statistical analysis process of the data obtained in the study. The normality of the variables in quantitative structure was examined by Kolmogorov Smirnov and Shapiro-Wilk tests. Pearson's chi-square test was used in the analysis of differences between groups for qualitative variables (gender, profession, education level). In 2x2 table configurations, in the presence of sparse eyes, Fisher exact test was used instead of Pearson chi-square test in analyses. In the process of revealing the relationship between two quantitative variables, Pearson's correlation coefficient was used. The significance, size and direction of the relationships are interpreted through the correlation coefficients. The upper limit for the statistical significance level in the study was determined as 0.05 .

\section{RESULTS}

The research was conducted with individuals between the ages of 10-15 who study in the fifth, sixth, seventh and eighth grades. When Table 1, which includes the general characteristics of the participants, is examined, the class distribution and occupation levels of mothers and fathers were found to be similar. In general, the conclusion to be drawn is that the profession of mothers was found to be housewives, and the profession of fathers was found as civil servant and free profession. When the BMI percentile values according to age are examined; $39.1 \%$ of the girls are overweight and $39.7 \%$ of the boys are obese. $60.3 \%$ of the adolescents participating in the study were overweight or obese.

When Table 2, which includes the relationship between the participants' EAQ scores and other characteristics, is examined, a positive correlation was found between age and both positive total score and negative total score $(\mathrm{p}<0.05)$. As the age increases, 
the total scores also increase. A statistically significant negative correlation was found of approximately $19 \%$ between positive total score and BMI percentile values. A statistically significant positive correlation was found between the positive total score and the consumption of energy, fat, polyunsaturated fatty acids (PUFA), monounsaturated fatty acids (MUFA), saturated fatty acids (SFA), omega 6, and sucrose.

When the cognitive functions evaluated according to the answers given by the students participating in the study to the D2 attention test were examined; The psychomotor speed is an indicator of how fast marking is being made and evaluated according to the TN score. $69.6 \%$ of female students and $86.3 \%$ of male students had a very good psychomotor speed level. The psychomotor speed level of male students is at a better level compared to female students $(p=0.044<0.05)$. There is no statistically significant difference between male and female students in terms of attention deficit, sustained attention problems, learning disability and fluctuation of attention (Table 3).

There is a positive correlation between TN (total number of items processed) and CP (concentration performance) scores and age, but also a significant negative correlation was found with the BMI z score. There is a positive correlation between energy, fat, PUFA, MUFA, SFA, cholesterol and omega 6 intake and the E2 (errors of commission) score $(\mathrm{p}<0.05)$. A positive correlation was observed between cholesterol and SFA intake and the E score (errors) $(\mathrm{p}<0.05)$. It was determined that there is a negative correlation between glucose intake and TN (total number of items processed) score. ( $p<0.05)$ (Table 4).

\section{DISCUSSION}

According to 2010 data from the Turkey Nutrition and Health Survey (TNHS), the BMI z score between the ages of $6-18,21.7 \%$ of girls and $23.3 \%$ of boys were overweight or obese. ${ }^{24}$ According to the results of both TNHS and this study, the frequency of obesity was higher in male individuals. Another study found that obesity in the 10-17 age group was more associated with adulthood obesity than obesity in the 1-9 age group. ${ }^{25}$ Nutritional habits developed during adolescence constitute a large part of the eating habits in adulthood. For this reason, it is important to detect and prevent additional body weight gain in the early period. There is a significant positive relationship between age and both positive and negative total scores. Individuals with a low body weight eat more in response to positive emotions than obese individuals. ${ }^{26}$ Although thin individuals exhibit emotional eating behaviours, lack of increase in body weight is associated with less bingeing behaviours compared to obese individuals. ${ }^{27}$

As the EAQ total scores increase, it is expected that energy, macro, and micronutrient consumption will also increase. Because an increase in these scores means an increase in the food intake of the individuals and therefore in their energy intake. In this study, in general, it was observed that as the energy macro and micronutrient intake of individuals increased, the positive total score increased. Participants consume more energy, fat and sugar in positive emotions and situations. These foods activate of individuals' reward system by increasing dopamine levels. Fat and sugar consumption can be associated with individuals rewarding themselves with these foods, linked either to positive or negative emotions. ${ }^{9,10}$ 
Table 1. General characteristics and BMI ${ }^{\mathrm{a}}$ values of the participants

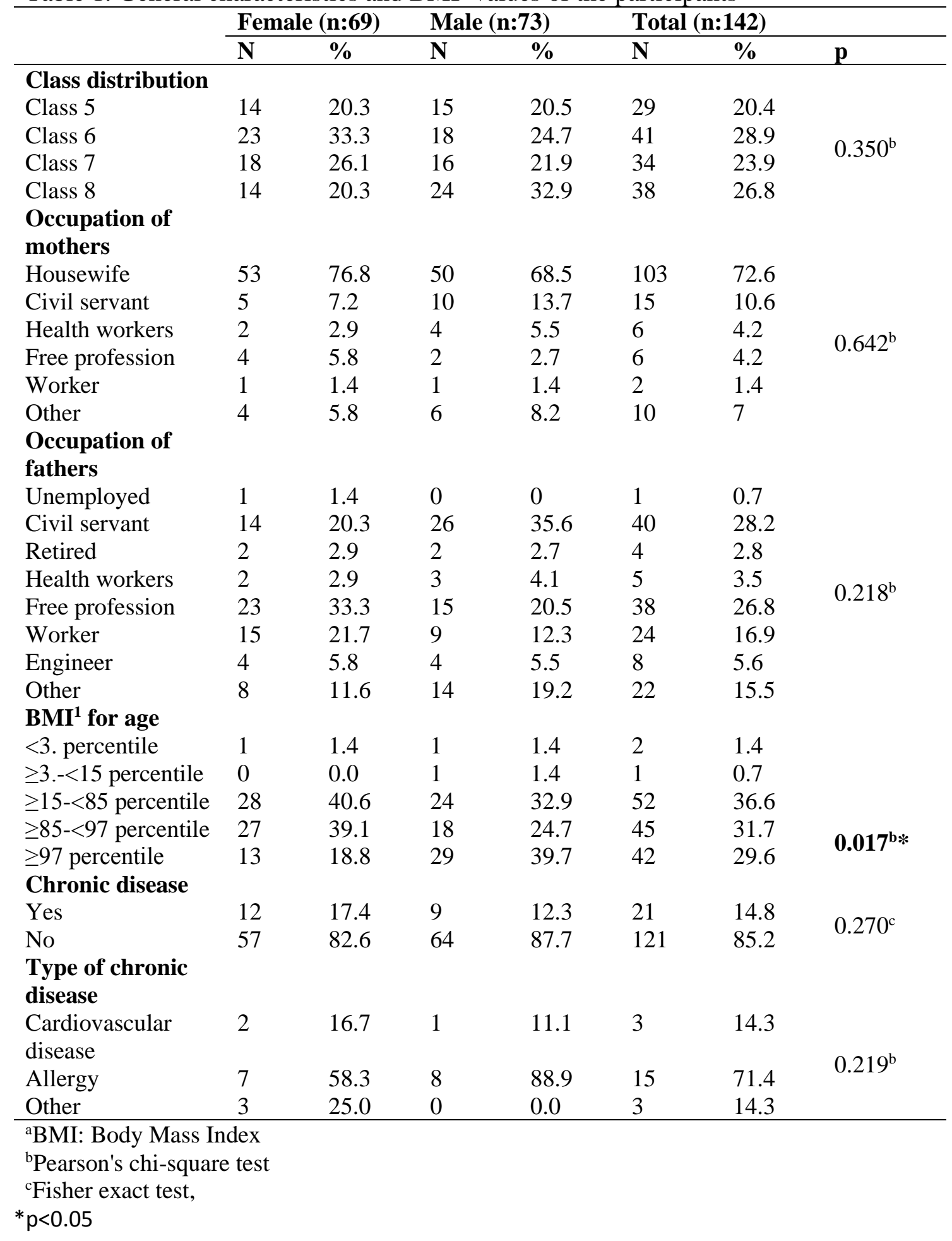

Thus, we found an increase in food consumption in positive emotions rather than negative emotions in adolescents. Other studies have also observed that individuals increase their food intake in more positive moods. ${ }^{27}$ It is thought that this situation is caused by individual differences such as genetic, environmental, and physiological 
Table 2. Relationship between EAQ ${ }^{1}$ scores, anthropometric measurements, and food consumption of the participants

\begin{tabular}{|c|c|c|c|c|}
\hline & \multicolumn{2}{|c|}{ Positive total score } & \multicolumn{2}{|c|}{ Negative total score } \\
\hline & $\mathbf{r}^{2}$ & $\mathbf{p}$ & $\mathbf{r}^{2}$ & $\mathbf{p}$ \\
\hline Age & $0.251^{*}$ & 0.003 & $0.250 *$ & 0.003 \\
\hline $\mathrm{BMI}^{3}$ for age & $-0.193 *$ & 0.021 & -0.090 & 0.284 \\
\hline Energy (kcal) & $0.213^{*}$ & 0.011 & 0.106 & 0.208 \\
\hline Carbohydrate (g) & 0.147 & 0.082 & 0.080 & 0.341 \\
\hline Protein (g) & 0.165 & 0.050 & 0.072 & 0.397 \\
\hline Fat (g) & $0.229 *$ & 0.006 & 0.110 & 0.191 \\
\hline Polyunsaturated fatty acid (g) & $0.200 *$ & 0.017 & 0.049 & 0.561 \\
\hline Saturated fatty acid (g) & $0.175^{*}$ & $\mathbf{0 . 0 3 7}$ & 0.131 & 0.120 \\
\hline Monounsaturated fatty acid (g) & $0.230 *$ & 0.006 & 0.088 & 0.300 \\
\hline Cholesterol (g) & 0.127 & 0.132 & 0.036 & 0.674 \\
\hline Omega 3 (g) & 0.134 & 0.113 & 0.084 & 0.320 \\
\hline Omega 6 (g) & $0.203^{*}$ & 0.015 & 0.042 & 0.619 \\
\hline Omega 6/3 & 0.043 & 0.612 & -0.013 & 0.875 \\
\hline Glucose (g) & 0.064 & 0.447 & 0.009 & 0.915 \\
\hline Fructose (g) & 0.104 & 0.218 & -0.010 & 0.906 \\
\hline Sucrose (g) & $0.185^{*}$ & 0.027 & 0.069 & 0.414 \\
\hline Fibre (g) & -0.017 & 0.839 & -0.014 & 0.870 \\
\hline
\end{tabular}

$* \mathrm{p}<0.05$

${ }^{1}$ Emotional Appetite Questionnaire

${ }^{2}$ Pearson Product Moment Correlation Coefficient

${ }^{3}$ Body Mass Index

changes. While food intake can increase during both positive and negative emotions, it can be said that individuals consume food by getting more pleasure in positive emotions, and tend to consume food in negative emotions due to the mechanism of escape from problems or impairment in physiological stimuli. ${ }^{7}$ In the long term, healthy eating habits can be acquired by making individuals aware of the situations such as hunger and satiety, the state of enjoying food, food intake despite the feeling of satiety, and food consumption in response to positive or negative emotions. It has been determined that providing individuals with 'eating awareness' regarding emotional eating behaviour is an effective method. ${ }^{28}$ More studies are needed to examine the effect of any emotional change on food intake, regardless of whether it is a positive or negative mood.

As in this study, in another study conducted on 34 healthy adolescents, it was observed that the Psychomotor Vigilance (wakefulness) Test performance was better in male than female students. This may be related to the more typical male strategy of being as fast as possible and the more common female strategy of answering as accurately as possible. $^{29}$

When the relationship between age and attention points is examined, in one study, it was observed that the psychomotor speed/TN score increased significantly with the 
Table 3. Evaluation of the cognitive functions of the participants according to the D2 attention test

\begin{tabular}{|c|c|c|c|c|c|c|c|}
\hline & \multicolumn{2}{|c|}{ Female (n:69) } & \multicolumn{2}{|c|}{ Male (n:73) } & \multicolumn{2}{|c|}{ Total (n:142) } & \multirow[b]{2}{*}{$\mathbf{p}$} \\
\hline & $\mathbf{N}$ & $\%$ & $\mathbf{N}$ & $\%$ & $\mathbf{N}$ & $\%$ & \\
\hline \multicolumn{8}{|c|}{ Psychomotor speed $^{1}$} \\
\hline Very good & 48 & 69.6 & 63 & 86.3 & 111 & 78.2 & \multirow{5}{*}{$0.044^{\mathrm{a} *}$} \\
\hline Good & 8 & 11.6 & 2 & 2.7 & 10 & 7.0 & \\
\hline Normal & 8 & 11.6 & 5 & 6.8 & 13 & 9.2 & \\
\hline Average & 4 & 5.8 & 3 & 4.1 & 7 & 4.9 & \\
\hline Poor & 1 & 1.4 & 0 & 0.0 & 1 & 0.7 & \\
\hline \multicolumn{8}{|c|}{ Attention deficit ${ }^{2}$} \\
\hline Yes & 12 & 17.4 & 6 & 8.2 & 18 & 12.7 & \multirow[b]{2}{*}{$0.131^{\mathrm{b}}$} \\
\hline No & 57 & 82.6 & 67 & 91.8 & 124 & 87.3 & \\
\hline \multicolumn{8}{|c|}{ Difficulties in sustained attention } \\
\hline Yes & 27 & 39.1 & 24 & 32.9 & 51 & 35.9 & \multirow{2}{*}{$0.486^{\mathrm{b}}$} \\
\hline No & 42 & 60.9 & 49 & 67.1 & 91 & 64.1 & \\
\hline \multicolumn{8}{|c|}{ Learning disability ${ }^{3}$} \\
\hline Possibly & 7 & 10.1 & 13 & 17.8 & 20 & 14.1 & \multirow{2}{*}{$0.231^{\mathrm{b}}$} \\
\hline No & 62 & 89.9 & 60 & 82.2 & 122 & 85.9 & \\
\hline \multicolumn{8}{|c|}{ Fluctuation of attention ${ }^{4}$} \\
\hline Yes & 56 & 81.2 & 64 & 87.7 & 120 & 84.5 & \multirow{2}{*}{$0.355^{\mathrm{b}}$} \\
\hline No & 13 & 18.8 & 9 & 12.3 & 22 & 15.5 & \\
\hline
\end{tabular}

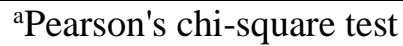

${ }^{\mathrm{b}}$ Fisher exact test,

${ }^{1}$ Evaluated by the \% TN score

${ }^{2}$ Evaluated by the \%(TN-E) score

${ }^{3}$ Evaluated by the E2>E1 Evaluated by the TN (max-min) $>7$

${ }^{*} \mathrm{p}<0.05$

grade level. ${ }^{30}$ In this study, as the age of the participants increases, the TN and CP (concentration performance) scores increase significantly. This situation may be associated with ongoing brain and motor function development in adolescents.

Increasing obesity can have negative effects, not only on physical, but also on cognitive functions. It is thought that cognitive functions such as psychomotor speed will be negatively affected because increased adipose tissue is linked to increased inflammation. In one study a significant negative correlation was observed in the D2 test between the CP and BMI . ${ }^{31}$ In this study, as the BMI z score of the participants was higher, the total and correct marking number was lower. The worse level of cognitive performance was observed in obese students.

The E2 score associated with impulsive behaviour was higher with higher fat consumption in our study. In a study conducted on 3240 students between the ages of 1315, a negative relationship was also observed between attention span and fast-food consumption. ${ }^{32}$ Impulsive behaviours can be associated with a low self-control mechanism and with the strain involved in attempting to avoid consumption (and associated pleasure) of high fat and sugar foods. ${ }^{33}$

A negative correlation was found between glucose consumption and the TN score, which is a psychomotor speed indicator. In one study, it was observed that glucose intake performed better in attention tests in the short term. ${ }^{34}$ However, in the long term, the 
Table 4. Relationship between the participants' food consumption and their D2 attention test scores

\begin{tabular}{|c|c|c|c|c|c|c|}
\hline & & \multicolumn{5}{|c|}{ D2 Attention Test Score } \\
\hline & & TN & E1 & E2 & $\mathbf{E}$ & $\mathbf{C P}$ \\
\hline \multirow{2}{*}{ Age } & $\mathrm{r}$ & $0.282^{*}$ & 0.111 & 0.026 & 0.019 & $0.275^{*}$ \\
\hline & $\mathrm{p}$ & 0.001 & 0.189 & 0.760 & 0.823 & 0.001 \\
\hline \multirow{2}{*}{ BMI for age } & $\mathrm{r}$ & $-0.226^{*}$ & -0.067 & 0.014 & 0.029 & $-0.206^{*}$ \\
\hline & $\mathrm{p}$ & 0.007 & 0.428 & 0.868 & 0.729 & 0.014 \\
\hline \multirow{2}{*}{ Energy (kcal) } & $\mathrm{r}$ & 0.105 & 0.092 & $\mathbf{0 . 1 7 2}^{*}$ & 0.109 & 0.054 \\
\hline & $\mathrm{p}$ & 0.213 & 0.276 & 0.040 & 0.196 & 0.524 \\
\hline \multirow{2}{*}{$\begin{array}{l}\text { Carbohydrate } \\
\text { (TE\%) }\end{array}$} & $\mathrm{r}$ & -0.021 & -0.066 & $-0.288^{*}$ & -0.111 & 0.077 \\
\hline & $\mathrm{p}$ & 0.803 & 0.436 & 0.001 & 0.190 & 0.361 \\
\hline \multirow{2}{*}{ Protein (TE\%) } & $\mathrm{r}$ & 0.118 & 0.036 & 0.048 & 0.006 & 0.085 \\
\hline & $\mathrm{p}$ & 0.162 & 0.670 & 0.572 & 0.948 & 0.316 \\
\hline \multirow{2}{*}{ Fibre (TE\%) } & $\mathrm{r}$ & -0.022 & 0.049 & $0.273^{*}$ & 0.104 & -0.109 \\
\hline & $\mathrm{p}$ & 0.798 & 0.563 & 0.001 & 0.219 & 0.196 \\
\hline \multirow{2}{*}{ PUFA (g) } & $\mathrm{r}$ & 0.018 & 0.061 & $0.209^{*}$ & 0.089 & -0.005 \\
\hline & $\mathrm{p}$ & 0.836 & 0.472 & 0.012 & 0.295 & 0.950 \\
\hline \multirow{2}{*}{ MUFA (g) } & $\mathrm{r}$ & 0.061 & 0.092 & $0.307^{*}$ & $0.168^{*}$ & -0.019 \\
\hline & $\mathrm{p}$ & 0.474 & 0.274 & 0.000 & 0.046 & 0.824 \\
\hline \multirow{2}{*}{ SFA (g) } & r & 0.144 & 0.082 & $0.238^{*}$ & 0.105 & 0.046 \\
\hline & $\mathrm{p}$ & 0.088 & 0.331 & 0.004 & 0.212 & 0.591 \\
\hline \multirow{2}{*}{ Cholesterol (g) } & r & 0.018 & 0.116 & $0.311^{*}$ & $0.211^{*}$ & -0.009 \\
\hline & $\mathrm{p}$ & 0.829 & 0.170 & 0.000 & 0.012 & 0.912 \\
\hline \multirow{2}{*}{ Omega 3 (g) } & $\mathrm{r}$ & -0.067 & 0.097 & 0.104 & 0.090 & -0.098 \\
\hline & $\mathrm{p}$ & 0.431 & 0.251 & 0.217 & 0.289 & 0.245 \\
\hline \multirow{2}{*}{ Omega 6 (g) } & $\mathrm{r}$ & 0.040 & 0.053 & $0.205^{*}$ & 0.079 & 0.022 \\
\hline & $\mathrm{p}$ & 0.638 & 0.527 & 0.014 & 0.348 & 0.797 \\
\hline \multirow{2}{*}{ Omega 6/Omega 3} & $\mathrm{r}$ & 0.081 & -0.050 & 0.143 & -0.012 & $0.182^{*}$ \\
\hline & $\mathrm{p}$ & 0.336 & 0.552 & 0.090 & 0.883 & 0.030 \\
\hline \multirow{2}{*}{ Glucose (g) } & $\mathrm{r}$ & $-0.175^{*}$ & 0.006 & -0.028 & 0.049 & -0.107 \\
\hline & $\mathrm{p}$ & 0.038 & 0.946 & 0.744 & 0.566 & 0.205 \\
\hline
\end{tabular}

BMI: Body Mass Index, TE: Total Energy, PUFA: Polyunsaturated fatty acid, MUFA:

Monounsaturated fatty acid, SFA: Saturated fatty acid, TN: Total number of items processed, E1: Errors of omission (number of unmarked correct answers), E2: Errors of commission (number of wrong answers marked), E: Errors (total error score), CP: Concentration performance (number of correct answers marked)

${ }^{*} \mathrm{p}<0.05$

Western diet (high monosaccharide, disaccharide and saturated fat) has negative effects on cognitive functions such as nutrition, memory and attention, physical health and quality of life. ${ }^{35}$ Prolonged consumption of sugar can desensitise dopaminergic receptors and cause a decrease in dopamine response. As a result, the control mechanism in the frontal cortex is inhibited and this in turn is associated with ADHD. ${ }^{36}$. Research on these issues has utilized differing the sample sizes, age ranges, inclusion and exclusion criteria, and differing measurement tools. More scientific studies are thus needed on this subject.

In this study, increased frequency of obesity and various dietary factors in adolescents affected attention and appetite scores. The presence of emotional eating habits is often associated with negative emotions. According to the results of this study, it can be said that food consumption increases in positive emotions rather than negative emotions in adolescents. Attention deficit was not observed in the majority of the 
participants. In addition, increased obesity, fat and sugar consumption and impaired cognitive performance were found. In order to maintain physical and cognitive health, it is very important for adolescents to acquire dietary habits that include adequate and balanced dietary patterns. More studies are needed to understand the relationship between the nutritional status of adolescents, emotional eating behaviour, and ADHD.

\section{REFERENCES}

1. Blakemore SJ, Burnett S, Dahl RE. The role of puberty in the developing adolescent brain. Human Brain Mapping. 2010;31(6):926-933. doi: 10.1002/hbm.21052

2. Wood CL, Lane LC, Cheetham T. Puberty: Normal physiology (brief overview). Best Practice \& Research Clinical Endocrinology \& Metabolism. 2019;33(3):101265. doi: 10.1016/j.beem.2019.03.001

3. American Psychological Association. Developing adolescents: a reference for professionals developing adolescents: a reference for professionals. 2002. https://www.apa.org/pubs/info/brochures/develop

4. Çelik G, Tahiroğlu A, Avcı A. Ergenlik döneminde beynin yapısal ve nörokimyasal değişimi. Klinik Psikiyatri. 2008;11:42-47.

5. Institute of Medicine (US) and National Research Council (US) Committee on the Science of Adolescence. The Science of Adolescent Risk-Taking: Workshop Report. Washington (DC): National Academies Press (US). 2011. doi: 10.17226/12961

6. Blakemore SJ. Imaging brain development: The adolescent brain. NeuroImage. 2012;61(2):397-406. doi: 10.1016/j.neuroimage.2011.11.080

7. İnalkaç $\mathrm{S}$, Arslantaş İ. Duygusal yeme. Arşiv Kaynak Tarama Dergisi. 2018;27(1):70-82. https://doi.org/10.17827/aktd.336860

8. Maxwell MA, Cole DA. Weight change and appetite disturbance as symptoms of adolescent depression: Toward an integrative biopsychosocial model. Clinical Psychology Review. 2009;29(3):260-273. doi: 10.1016/j.cpr.2009.01.007

9. Sevinçer GM, Konuk N. Emosyonel yeme. Journal of Mood Disorders. 2013;3(4):171-178. doi: 10.5455/jmood.20130926052526

10. Şanlıer N, Serin Y. Duygusal yeme, besin alımını etkileyen faktörler ve temel hemşirelik yaklaşımları. Psikiyatri Hemşireliği Dergisi. 2018;9(2):135146. doi: $10.14744 /$ phd.2018.23600

11. Strien TV, Zwaluw CS, Engels RCME. Emotional eating in adolescents: A gene (SLC6A4/5-HTT) - Depressive feelings interaction analysis. Journal of Psychiatric Research. 2010;44(15):1035-1042. doi:

10.1016/j.jpsychires.2010.03.012

12. Lindsay GW. Attention in psychology, neuroscience, and machine learning. Frontiers in Computational Neuroscience. 2020;14. doi: 10.3389/fncom.2020.00029

13. Dinçer ED, Karakaş S. Nöropsikolojik dikkat testleri arasındaki ilişkilerin modellenmesi. Klinik Psikofarmakoloji Bülteni. 2008;18:31-40 
14. Griffiths KR, Quintana DS, Hermens DF, et al. Sustained attention and heart rate variability in children and adolescents with ADHD. Biological Psychology. 2017;124:11-20. doi: 10.1016/j.biopsycho.2017.01.004

15. Kim KM, Lim MH, Kwon HJ, et al. Associations between attentiondeficit/hyperactivity disorder symptoms and dietary habits in elementary school children. Appetite. 2018;127:274-279. doi:

10.1016/j.appet.2018.05.004

16. Verlaet AAJ, Noriega DB, Hermans N, Savelkoul HFJ. Nutrition, immunological mechanisms and dietary immunomodulation in ADHD.

European Child \& Adolescent Psychiatry. 2014;23:519-529. doi: 10.1007/s00787-014-0522-2

17. Schnoll R, Burshteyn D, Cea-Aravena J. Nutrition in the treatment of attention-deficit hyperactivity disorder: A neglected but important aspect. Applied Psychophysiology and Biofeedback. 2003;28(1):63-75. https://doi.org/10.1023/A:1022321017467

18. Pelsser LMJ, Frankena K, Toorman J, et al. Effects of a restricted elimination diet on the behaviour of children with attention-deficit hyperactivity disorder (INCA study): a randomised controlled trial. The Lancet. 2011;377(9764):494-503. doi: https://doi.org/10.1016/S01406736(10)62227-1

19. Pelsser LMJ, Frankena K, Toorman J, Savelkoul HFJ, Pereira RR, Buitelaar JK. A randomised controlled trial into the effects of food on ADHD. European Child \& Adolescent Psychiatry. 2009;18:12-19. doi: 10.1007/s00787-008-0695-7

20. WHO. Growth Reference 5-19 years.2007. https://www.who.int/growthref/who2007_bmi_for_age/en/

21. Brickencamp, R. D2 Aufmerksamkeits- Belastungs. Test: Handanweisung. Göttingen: Hofrere. 198.

22. Nolan LJ, Halperin LB, Geliebter A. Emotional appetite questionnaire. Construct validity and relationship with BMI. Appetite. 2010;54(2):314-319. doi: 10.1016/j.appet.2009.12.004

23. Demirel B, Yavuz F, Karadere ME, Şafak Y, Türkçapar MH. Duygusal iştah anketi'nin türkçe geçerlik ve güvenilirliği, beden kitle indeksi ve duygusal şemalarla ilişkisi. Bilişsel Davranışçı Psikoterapi ve Araştırmalar Dergisi. 2014;3:171-181.

24. Türkiye Beslenme ve Sağlık Araştırması. Sağlık Bakanlığı Sağlık Araştırmaları Genel Müdürlüğü. 2014. https://hsgm.saglik.gov.tr/depo/birimler/saglikli-beslenme-hareketli-hayatdb/Yayinlar/kitaplar/diger-kitaplar/TBSA-Beslenme-Yayini.pdf

25. You J, Choo J. Adolescent overweight and obesity: links to socioeconomic status and fruit and vegetable intakes. Int. J. Environ. Res. Public Health. 2016;13(3):307. doi: 10.3390/ijerph13030307

26. Geliebter A, Aversa A. Emotional eating in overweight, normal weight, and underweight individuals. Eat Behav. 2003;3(4):341-347. doi: 10.1016/s14710153(02)00100-9

27. Bongers P, Jansen A, Houben K, Roefs A. Happy eating: the single target implicit association test predicts overeating after positive emotions. Eat Behav. 2013;14(3):348-355. doi: 10.1016/j.eatbeh.2013.06.007 
28. Çolak H, Aktaç Ş. A ğırlık yönetimine yeni bir yaklaşım: yeme farkındalığı. Adnan Menderes Üniversitesi Sağlık Bilimleri Fakültesi Dergisi 2019;3(3):212-222.

29. Beijamini F, Silva AGT, Peixoto CAT, Louzada FM. Influence of gender on psychomotor vigilance task performance by adolescents. Brazilian Journal of Medical and Biological Research. 2008;41(8):734-738. https://doi.org/10.1590/S0100-879X2008000800016

30. Wassenberg R, Hendriksen JG, Hurks PP, et al. Development of inattention, impulsivity, and processing speed as measured by the $\mathrm{d} 2$ Test: results of a large cross-sectional study in children aged 7-13. Child Neuropsychol. 2008;14(3):195-210. doi: 10.1080/09297040601187940

31. Cserjési R, Molnár D, Luminet O, Lénárd L. Is there any relationship between obesity and mental flexibility in children? Appetite. 2007;49(3):675-678.

32. Kaur M. Fast food consumption and its relation with attention span and memory retention in school children. Studies on Ethno-Medicine. 2019;13(1):17-26. doi: 10.1016/j.appet.2007.04.001

33. Güngör S, Celiloğlu ÖS, Raif SG, Özcan ÖÖ, Selimoğlu MA. Malnutrition and obesity in children with ADHD. Journal of Attention Disorders. 2016;20(8):647-652. doi: 10.1177/1087054713478465

34. Gagnon C, Greenwood CE, Bherer L. The acute effects of glucose ingestion on attentional control in fasting healthy older adults. Psychopharmacology. 2010;211:337-346. doi: 10.1007/s00213-010-1905-9

35. Hauser J, Stollberg E, Reissmann A, Kaunzinger I, Lange KW. Effects of omega-3 fatty acids and sugar on attention in the spontaneously hypertensive rat. Journal of Functional Foods. 2018;48:676-681. https://doi.org/10.1016/j.jff.2018.07.057

36. Del-Ponte B, Anselmi L, Assunçao MCF, Tovo-Rodrigues L, Munhoz TN, Matjijasevich A, Rohde LA, Santos IS. Sugar consumption and attentiondeficit/hyperactivity disorder (ADHD): A birth cohort study. Journal of Affective Disorders. 2019;243:290-296. doi: 10.1016/j.jad.2018.09.051 